\title{
Accidental nasal fossa perforation during endodontic treatment - Case report
}

\author{
Perfuração acidental da fossa nasal durante tratamento endodôntico - Relato de caso \\ Perforación accidental de la fosa nasal durante el tratamiento de endodoncia - Reporte de caso
}

Kim Henderson Carmo Ribeiro ORCID: https://orcid.org/0000-0003-3325-5897 Universidade Estadual Paulista, Brasil E-mail: kimhenderson@hotmail.fr Neylla Teixeira Sena ORCID: https://orcid.org/0000-0002-5598-011X Universidade do Estado do Amazonas, Brasil E-mail: neylla2002@yahoo.com.br Joel Motta Junior

ORCID: https://orcid.org/0000-0003-0272-5163 Universidade do Estado do Amazonas, Brasil E-mail: jmotta@uea.edu.br

Marcia Raquel Costa Lima Braga ORCID: https://orcid.org/0000-0001-7496-2243

Universidade do Estado do Amazonas, Brasil E-mail: mrbraga@uea.edu.br

Ana Carolyna Becher Roseno

ORCID: https://orcid.org/0000-0002-1227-5947 Universidade Estadual Paulista, Brasil E-mail: carolbecherr@gmail.com

Ana Julia Moreno Barreto

ORCID: https://orcid.org/0000-0002-0067-1192 Universidade Estadual Paulista, Brasil

E-mail: anajuliamorenobarreto1 @ hotmail.com

Mariza Akemi Matsumoto

ORCID: https://orcid.org/0000-0001-5389-0105 Universidade Estadual Paulista, Brasil

E-mail: mariza.am@gmail.com

\begin{abstract}
Fracture of an endodontic instrument within the root canal system can occur due to incorrect use of instruments, and clinicians are confronted with a few removal options when considering this situation. The purpose of this article is to present the removal of a fractured endodontic file from the periapical region of the right upper central incisor, that caused a nasal floor perforation and otorhinolaryngological symptoms, with the aid of a dental operating microscope (DOM) and cone bean computed tomography (CBCT). Success was achieved when the fragment was visible and removed from the nasal fossa. The standardized techniques of removal or bypassing fracture file were not effective, and success was obtained with the aid of CBCT that made possible the visualization of the broken file inside the nasal fossa.
\end{abstract}

Keywords: Root canal therapy; Ultrasonics; Nasal cavity; Endodontics; Cone beam computed tomography.

\section{Resumo}

A fratura de um instrumento endodôntico dentro do sistema de canais radiculares pode ocorrer devido ao uso incorreto dos instrumentos. O clínico se depara com algumas opções de remoção ao considerar essa situação. O objetivo deste artigo é apresentar a retirada de uma lima endodôntica fraturada da região periapical do incisivo central superior direito, acarretando em uma perfuração da fossa nasal associado a sintomas otorrinolaringológicos, com o auxílio de microscópio cirúrgico odontológico e tomografia computadorizada de feixe cônico (TCFC). O sucesso foi alcançado quando o fragmento foi visível e empurrado para fora da fossa nasal. As técnicas padronizadas utilizadas neste caso para a retirada ou transpassando a lima fraturada não foram eficazes, e o sucesso foi obtido com o auxílio da TCFC e o fragmento foi visível no interior da fossa nasal.

Palavras-chave: Tratamento do canal radicular; Ultrassom; Cavidade nasal; endodontia; Tomografia computadorizada de feixe cônico.

\section{Resumen}

La fractura de un instrumento endodóntico dentro del sistema del conducto radicular puede ocurrir debido al uso incorrecto de los instrumentos. El médico se enfrenta a algunas opciones de extracción al considerar esta situación. El 
objetivo de este artículo es presentar la extracción de una lima endodóntica fracturada de la región periapical del incisivo central superior derecho, que ocasiona perforación del piso nasal y síntomas otorrinolaringológicos, con la ayuda de un microscopio quirúrgico dental y con tomografía computarizada de haz cónico (TCHC). El éxito se logró cuando el fragmento era visible y se expulsaba de la fosa nasal. Las técnicas estandarizadas que se utilizaron en este caso para la extracción o bypassing de la lima no fueron efectivas, y el éxito se logró con la ayuda del TCHC y el fragmento quedó visible dentro de la fosa nasal.

Palabras clave: Tratamiento del conducto radicular; Ultrassonido; Cavidad nasal; Endodoncia; Tomografía computarizada de haz cónico.

\section{Introduction}

Among the phases of endodontic treatment, biomechanical preparation deserves special attention, when accidents are more prone to occur such as deviations, perforations and instrument fractures, since some teeth can present intrinsic factors as complex anatomy with the presence of sharp curvatures, atresia and calcifications (Cujé, et al., 2010; Ungerechts, et al., 2014; Sarao, et al., 2020).

The prevalence of fractured instruments ranges from $0.5-5 \%$ and it can occur within or beyond the root canal (Nevares, et al., 2012). When an instrument fractures in the root canal system, the decision of leaving it in the root canal, bypass, or remove the fragment has to be made, based on a potential benefit of completely removing it, or the risk of a complication (Setzer, et al., 2010; Nevares, et al., 2012; McGuigan, et al., 2013). When an instrument fractures beyond the root foramen, periapical and otorhinolaryngological problems may occur (Wang, et al., 2010; Panitvisai, et al., 2010), and frequently, removal of the fractured instrument is the best option.

Technological advancements such as the dental operating microscope (DOM), ultrasonics and cone beam computed tomography (CBCT), have improved diagnosis and enhance visualization of the operative field. When combined, successes rates are increased (Wang, et al., 2010; Panitvisai, et al., 2010; McGuigan, et al., 2013; Fu, et al., 2018). However, even if file removal is successful, it does not mean that accidents cannot happen (Gandevivala, et al., 2014; Ramos Brito, et al., 2017). Although unusual, nasal cavity perforation is a condition that can occur during surgical procedure. The present case reports a file fracture instrument removal, that perforated the nasal floor.

\section{Metodology}

This work aimed to report a case in a descriptive and qualitative way according to Pereira et al. (2018), about a specific subject, detailed to highlight its particularities and expose the treatment of an accident caused by a fracture of an endodontic file in the region of the upper right central incisor, which resulted in perforation of the nasal fossa and consequent otorhinolaryngological symptoms to the patient. The presentation of the case was authorized by the patient and his family through the Informed Consent Term (ICT), written in easy-to-understand language so that they were aware of the destination of the personal information collected, as well as the associated risks and benefits, based on treatments supported by the literature (Fu, et al., 2018 \& Sapmaz, et al., 2019), through the search for scientific articles and case studies.

\section{Case Report}

\section{Medical History and Findings}

A thirteen years old patient, with noncontributory general medical history, was referred to the specialization Program in Endodontics of Amazon State University (UEA), for fracture file (\#40 K) removal, after endodontic urgency, done one week before.

During the first visit, patient confirmed that no x-ray was performed before or during treatment, showing lack of care, planning, and not taking into account the length of the tooth and its anatomy. The patient complained of nasal discomfort after 
endodontic treatment, done one week before, such as increased sneezing, crusting and foul smell. Patient denied spontaneous pain in the associated tooth but reported painful symptomatology upon vertical percussion and mastication. Pulp test with carbon dioxide snow was negative. Further intraoral examination revealed a healthy periodontium, the buccal mucosa presented normal color and appearance and no gingival or extraoral swelling were observed.

\section{Diagnosis and Treatment concept}

Periapical radiographic examination confirmed the presence of an endodontic instrument beyond the apical foramen of the right maxillary central incisor (\#11) (Figure 1A). Sensitivity on vertical percussion and pain on mastication were consistent with the diagnosis of fracture endodontic instrument beyond apical foramen. The advantages and risks of various therapeutic options were discussed with the patient and his/her parents, who at first, chose by the removal of the fractured instrument via dental canal. However, some important findings during the procedure were revealed and surgical intervention was necessary, as described below.

\section{Treatment}

After local anesthesia, dental operating microscope (DOM) allowed the visualization of the fragment (Figure 1B). The treatment was divided into 3 phases spread over 4 sessions (Table 1). Fragment removal was attempted using ultrasonic vibrations around the file and abundant irrigation with chlorhexidine. There was no success of the technique and bypassing technique was attempted using a hand stainless steel K-file 25mm \#10 and \#15 (Cpilot $($ )), however it was no successful either. Then, temporary restoration was performed (Figure 1C).

Table 1 - The Treatment Concept For Fragment Removal.

\begin{tabular}{|c|c|}
\hline $\begin{array}{l}\text { Treatment } \\
\text { Phases }\end{array}$ & Sessions \\
\hline $\begin{array}{l}\text { Phase } 1 \\
\text { Primary } \\
\text { removal } \\
\text { treatment }\end{array}$ & $\begin{array}{l}\text { 1st session } \\
\text { - Periapical radiograph, confirming the presence of fractured file } \\
\text { beyond the apical foramen } \\
\text { - Visualization of the fractured file using operating microscope } \\
\text { - Ultrasonic vibrations around the fragment and chlorhexidine } \\
\text { irrigation } \\
\text { - Bypassing technique }\end{array}$ \\
\hline $\begin{array}{l}\text { Phase } 2 \\
\text { Secondary } \\
\text { removal } \\
\text { treatment } \\
\text { and CBCT } \\
\text { request }\end{array}$ & $\begin{array}{l}\text { 2nd session (1 week after 1st session) } \\
\text { - File tip into the nasal fossa visualize by CBCT aid } \\
\text { - Fragment removal by pushing through nasal cavity and } \\
\text { removed by the dental crown } \\
\text { - Conservative treatment for the nasal floor perforation } \\
\text { (physiological saline recommended twice a day for a week) } \\
\text { - Intracanal medication (UltraCal®) for } 7 \text { days }\end{array}$ \\
\hline $\begin{array}{l}\text { Phase } 3 \\
\text { Root canal } \\
\text { therapy }\end{array}$ & $\begin{array}{l}\text { 3rd session (1 week after 2nd session) } \\
\text { - Endodontic instrumentation using manual files combine with } \\
\text { ultrasound EDTA agitation. } \\
\text { - Root canal obturation } \\
\text { 4th session ( } 2 \text { weeks after } 3 \text { rd session) } \\
\text { - Fiber pin cementation } \\
\text { - Tooth restauration with composite }\end{array}$ \\
\hline
\end{tabular}

Source: Personal archive. 
Figure 1. A: Periapical radiograph showing fracture file beyond apical foramen at tooth \#11. B: Intracanal fragment visualization. C: Temporary restoration using glass ionomer.

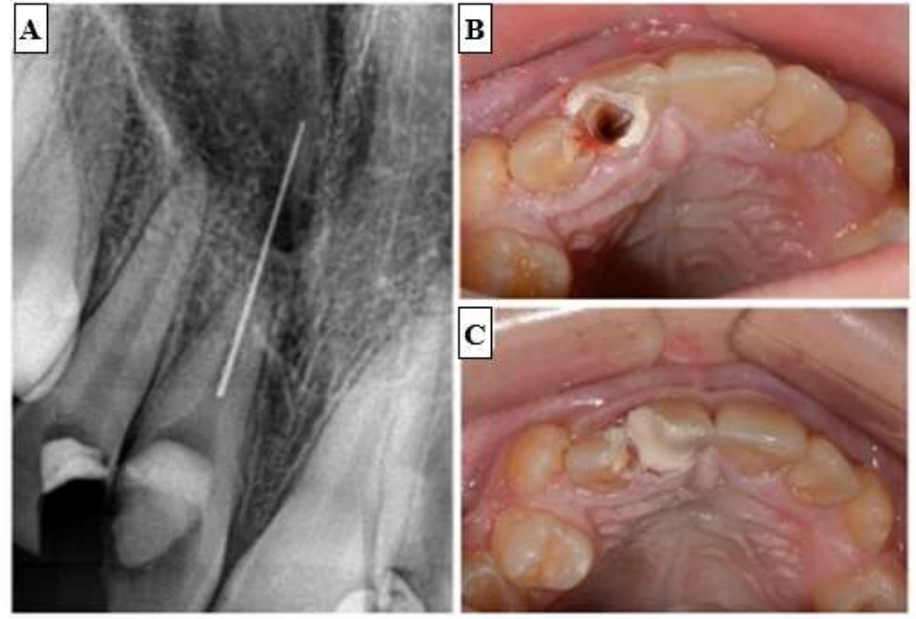

Source: Personal archive.

Considering the limitations of periapical $\mathrm{x}$-ray, $\mathrm{CBCT}$ was requested and revealed the tip of the file in the nasal fossa (Figure 2A, B and C) and surgical approach was opted. In the second session, the patient was prepared for surgery and during the examination, the tip of the instrument was visualized in the patient's nasal fossa (Figure 2D) and then it was decided to push the fragment through the handle of a clinical clamp. The fragment was removed (Figure 2E and F) using clinical forceps, under local anesthesia. The nasal fossa perforation size was very small, requiring no surgical procedure. Then, a gentle endodontic instrumentation was performed in the associated tooth, using $0.12 \%$ chlorhexidine gel as irrigation substance, and calcium hydroxide 35\% (UltraCal ${ }^{\circledR}$ ) was used as an intracanal medication for seven days. As a conservative treatment for the nasal perforation, physiological saline solution was recommended for the daily nasal irrigation, twice a day for a week. 
Figure 2. A: CBCT 3D reconstruction showing file protruded into nasal fossa. B: CBCT coronal cut and file length measurement. C: CBCT axial cut and file dimension measurement. D: Tip of the file inside patient nasal fossa. E: File removal and nasal fossa perforation examination. F: Removed fractured file and measurement.

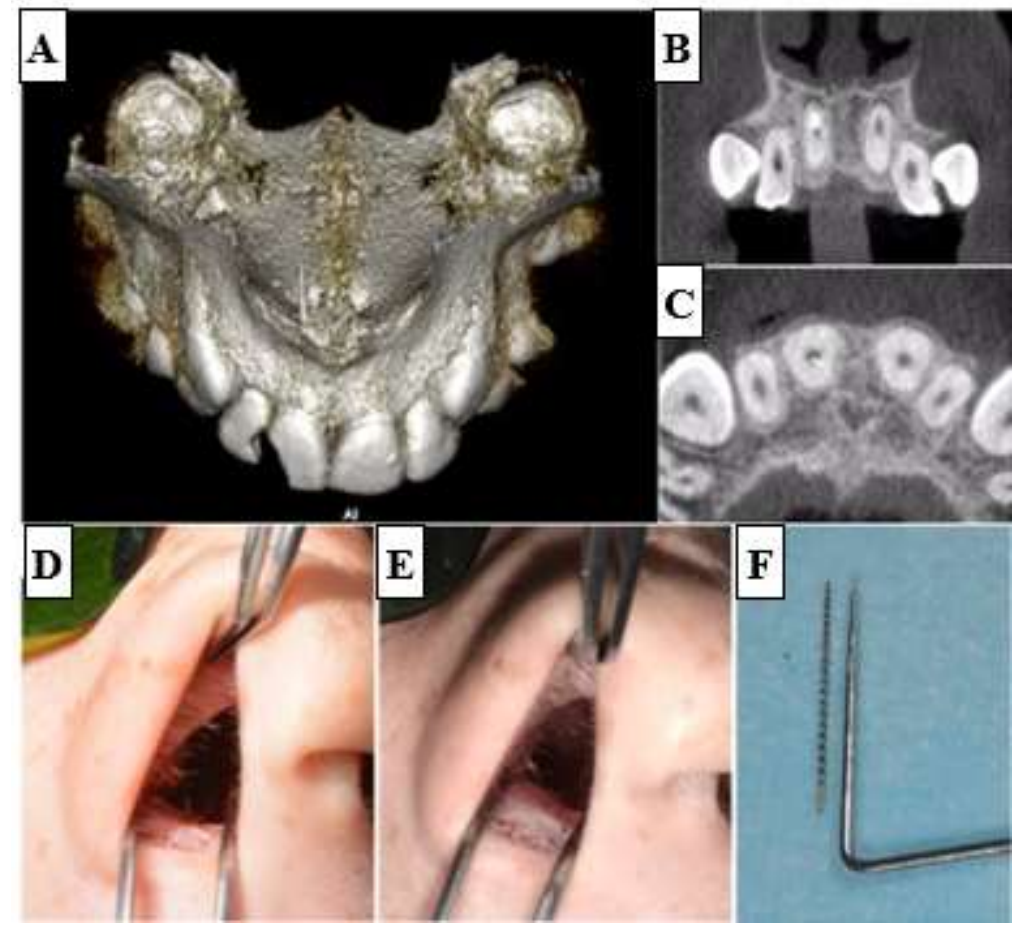

Source: Personal archive.

In the third and last session, endodontic instrumentation (Figure 3A) was performed using manual files associated with the EDTA ultrasound agitation. Due to the great amplitude of root canal (Figure 3B), medium gutta-percha (Odous de Deus $\left.{ }^{\circledR}\right)$ point was used to the apical portion, then the remaining portion of the root canal was sealed with thermoplastic obturation of gutta-percha.

Root reinforcement was performed with fiber pin cementation and composite resin restoration (Figure 3C) fifteen days after endodontic treatment.

The dental operating microscope aid to visualize the fractured instrument from root canal, however periapical radiography didn't permit to visualize the spacial relationship of the tip, to the adjacents areas and its impaction. Thus, attempt of removal the file fragment followed by bypassing failed. After diagnosis, with CBCT, success was achieve by pushing the fragment from the nasal fossa to the root canal, and removal by the aid of a clamp through the dental crown.

The clinical and radiographic findings at the 15-day follow-up visit, showed no pathologic findings, or painful symptomatologie. After 2 months, periapical tissue mineralization was observed, which presented previous periradicular lesions, which presented the absence of periapical thickening. The patient's clinical case has been followed for two years, with no symptoms. 
Figure 3. A: Intracanal aspect after endodontic instrumentation. B: Intracanal medication with calcium hydroxide $35 \%$ (UltraCal®).C: Composite resin final restoration of the \#11.
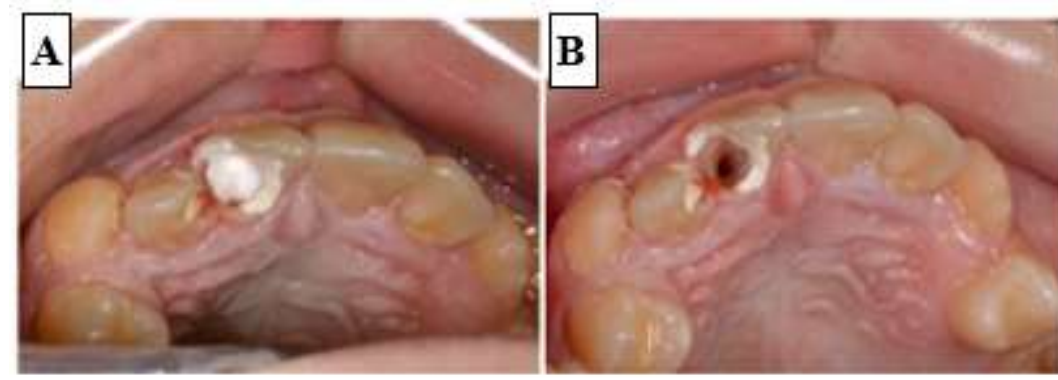

Source: Personal archive.

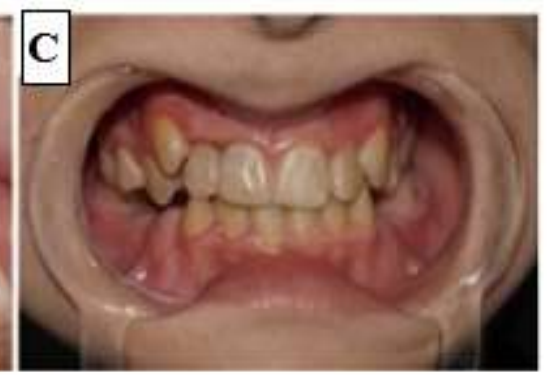

\section{Discussion}

Endodontic biomechanical preparation needs to be carefully realized, to avoid accidents. One of the most common accident during an endodontic treatment is file fracture and before attempted the instrument removal, some factors may be considered, and balanced the chances of success against complications (Nevares, et al., 2012). When accidents such as file fracture happen, many removals techniques are described ate the literature (McGuigan, et al., 2013; Ungerechts, et al., 2014; Sarao, et al., 2020). Some studies indicate that success in removing fractured instruments depends on intrinsic factors of the tooth, such as canal anatomy, degree of curvature of the canal, fractured instrument type and its location and the specific technique used (Cujé, et al., 2010; Ungerechts, et al., 2014).

Dental operating microscope (DOM) and ultrasonics tips have enabled enhanced visualization of the operative field, allowing clinical better success rates of approximately $74 \%$ (Fu, et al., 2018). In the present case, DOM allowed visualization of fragment and ultrasonic tips were opted to use, around the fractured instrument. However due to the impossibility of removal, unnecessarily vigorous use of ultrasound could lead to adverse outcomes such as deviations, perforations or even weakening of the root canal. Unfortunally, the presence of an instrument in the root canal, might lead to a poor prognosis, when the possibility to clean the entire working length of the root canal is not possible (McGuigan et al., 2013).

When DOM and ultrasound-aided removal does not show outcomes, bypassing can be attempted, with the purpose of bypass the fractured fragment by using hand stainless steel files and manual instrumentation (Nevares et al., 2013 \& McGuigan et al. 2013). When the fragment retrieval is not enable, some authors recommend full bypassing, manual instrumentation, abundant irrigation of the canal and then sealed the fragment into the obturation (Ungerechts, et al., 2014). In the present study, bypass was attempt using a manual K-file, however showing no sucess, due to the impaction of the file inside the canal, and its location more apically. To increase removal success and the same time provide more technical security in accessing those instruments, cone beam computed tomography (CBCT) can assist in success (D'Addazio, et al., 2011), helping to examined smaller parts of the dentomaxillofacial area (Wang, et al., 2010; D'Addazio, et al., 2011; Ball, et al., 2013 Gandevivala, et al., 2014 as requested to our patient, allowing a more detailed information concerning the type and dize of the fractured instrument and it was possible to evaluated the file location protruded into the nasal floor and its precise spatial relationships to the nasal fossa was obtained, being possible diagnosis and treatment planning. 
Based on the findings, endodontic surgery was the treatment of choice. Teeth with fractured instruments extending into maxillary anatomical areas might be an aetiological factor for otorhinolaryngological symptoms (Gandevivala, et al., 2014; Ramos Brito, et al., 2017). Nasal cavity perforation is a condition characterized by loss of cartilage and/or bony structures along with their mucoperichondrium and mucoperiosteum and it may be due to surgical iatrogenic (Lee, et al., 2010; Sapmaz, et al., 2019). Patients can complain of wheezing, nasal crusting, runny nose, sensation of nasal obstruction, foul odor, anosmia, as well as formation of crusts and nasal bleeding, however most patients are asymptomatic (Brain, 1980; Lee, et al., 2010; Sapmaz, et al., 2019). In this report, patient complained of foul smell, as well of nasal discomfort sneezing and crusting. Computed tomography is also helpful for classify the perforation and its relation with other elements of the nasal anatomy. While nasal fossa perforation can be treated with many surgical techniques described in the literature, it can also be conservative, symptomatically treated with moisturizing creams and nasal irrigation (Brain, 1980; Sapmaz, et al., 2019) as it was opted in the present case, due to the small perforation size, where the patient was prescribed only with physiological saline solution for the daily nasal irrigation, twice a day for a week.

The results of the follow-up examinations of the present case indicate that the method chosen depends of many intrinsic and extrinsic factors. In this case, after a good visualization of the fragment into the nasal fossa, the decision was made to push the file into the root canal in an attempt to conserve the tooth and remove the instrument from the crown. The chosen technique was successful and the otorhinolaryngological symptoms were eliminated.

\section{Conclusion}

Fractured instruments can be removed by a variety of methods such as fine ultrasonic tips, bypassing and forceps. Although many of these techniques have been described as successful, they require skilled use and the association of the operating microscope and computed tomography generally secure high success rates. Patients should be informed if an instrument fractures during treatment and the clinician needs to secure a cost-benefit analysis of the treatment before selecting a definitive treatment for the patient.

This report concludes that once a fractured file is diagnosed, clinicians should identify the type of fracture and its relation to other spaces such as the nasal fossa. CBCT contribute to successful removal of fractured instruments and assist the type of treatment about nasal fossa perforation. Good experience and an appropriate armamentarium enable successful management of complicated cases. Nasal fossa perforation is not a common accident due to endodontic treatment and if the patient has otorhinolaryngological involvement, follow-up with a specialist such as the maxillofacial surgeon or otorhinolaryngologist is suggested.

\section{References}

Ball, R. L., Barbizam, J. V., \& Cohenca, N. (2013). Intraoperative endodontic applications of cone-beam computed tomography. Journal of endodontics, 39(4), 548-557. https://doi.org/10.1016/j.joen.2012.11.038

Brain D. J. (1980). Septo-rhinoplasty: the closure of septal perforations. The Journal of laryngology and otology, 94(5), 495-505. https://doi.org/10.1017/s0022215100089179

Cannon, D. E., Frank, D. O., Kimbell, J. S., Poetker, D. M., \& Rhee, J. S. (2013). Modeling nasal physiology changes due to septal perforations. Otolaryngology--head and neck surgery: official journal of American Academy of Otolaryngology-Head and Neck Surgery, 148(3), 513-518. https://doi.org/10.1177/0194599812472881

Cujé, J., Bargholz, C., \& Hülsmann, M. (2010). The outcome of retained instrument removal in a specialist practice. International endodontic journal, 43(7), 545-554. https://doi.org/10.1111/j.1365-2591.2009.01652.x

D'Addazio, P. S., Campos, C. N., Özcan, M., Teixeira, H. G., Passoni, R. M., \& Carvalho, A. C. (2011). A comparative study between cone-beam computed tomography and periapical radiographs in the diagnosis of simulated endodontic complications. International endodontic journal, 44(3), 218-224. https://doi.org/10.1111/j.1365-2591.2010.01802.x 
Fu, M., Huang, X., He, W., \& Hou, B. (2018). Effects of ultrasonic removal of fractured files from the middle third of root canals on dentinal cracks: a microcomputed tomography study. International endodontic journal, 51(9), 1037-1046. https://doi.org/10.1111/iej.12909

Gandevivala, A., Parekh, B., Poplai, G., \& Sayed, A. (2014). Surgical removal of fractured endodontic instrument in the periapex of mandibular first molar. Journal of international oral health: JIOH, 6(4), 85-88. Retirado de: https://www.ncbi.nlm.nih.gov/pmc/articles/PMC4148581/

Hülsmann, M., \& Schinkel, I. (1999). Influence of several factors on the success or failure of removal of fractured instruments from the root canal. Endodontics \& dental traumatology, 15(6), 252-258. https://doi.org/10.1111/j.1600-9657.1999.tb00783.x

Lee, H. P., Garlapati, R. R., Chong, V. F., \& Wang, D. Y. (2010). Effects of septal perforation on nasal airflow: computer simulation study. The Journal of laryngology and otology, 124(1), 48-54. https://doi.org/10.1017/S0022215109990971

McGuigan, M. B., Louca, C., \& Duncan, H. F. (2013). Clinical decision-making after endodontic instrument fracture. British dental journal, 214(8), 395-400. https://doi.org/10.1038/sj.bdj.2013.379

McGuigan, M. B., Louca, C., \& Duncan, H. F. (2013). The impact of fractured endodontic instruments on treatment outcome. British dental journal, 214(6), 285-289. https://doi.org/10.1038/sj.bdj.2013.271

Nevares, G., Cunha, R. S., Zuolo, M. L., \& Bueno, C. E. (2012). Success rates for removing or bypassing fractured instruments: a prospective clinical study. Journal of endodontics, 38(4), 442-444. https://doi.org/10.1016/j.joen.2011.12.009

Panitvisai, P., Parunnit, P., Sathorn, C., \& Messer, H. H. (2010). Impact of a retained instrument on treatment outcome: a sy stematic review and meta-analysis. Journal of endodontics, 36(5), 775-780. https://doi.org/10.1016/j.joen.2009.12.029

Ramos Brito, A. C., Verner, F. S., Junqueira, R. B., Yamasaki, M. C., Queiroz, P. M., Freitas, D. Q., \& Oliveira-Santos, C. (2017). Detection of Fractured Endodontic Instruments in Root Canals: Comparison between Different Digital Radiography Systems and Cone-beam Computed Tomography. Journal of endodontics, 43(4), 544-549. https://doi.org/10.1016/j.joen.2016.11.017

Sapmaz, Emrah, Toplu, Yuksel, \& Somuk, Battal Tahsin. (2019). A new classification for septal perforation and effects of treatment methods on quality of life. Brazilian Journal of Otorhinolaryngology, 85(6), 716-723. Epub. https://dx.doi.org/10.1016/j.bjorl.2018.06.003

Sarao SK, Berlin-Broner Y \& Levin L. (2020). Occurrence and risk factors of dental root perforations: a systematic review. International Dental Journal. https://doi.org/10.1111/idj.12602

Setzer, F. C., Shah, S. B., Kohli, M. R., Karabucak, B., \& Kim, S. (2010). Outcome of endodontic surgery: a meta-analysis of the literature--part 1: Comparison of traditional root-end surgery and endodontic microsurgery. Journal of endodontics, 36(11), 1757-1765. 10.1016/j.joen.2010.08.007

Ungerechts, C., Bårdsen, A., \& Fristad, I. (2014). Instrument fracture in root canals - where, why, when and what? A study from a student clinic. International endodontic journal, 47(2), 183-190. https://doi.org/10.1111/iej.12131

Wang, H., Ni, L., Yu, C., Shi, L., \& Qin, R. (2010). Utilizing spiral computerized tomography during the removal of a fractured endodontic instrument lying beyond the apical foramen. International endodontic journal, 43(12), 1143-1151. https://doi.org/10.1111/j.1365-2591.2010.01780.x 